\title{
SOCIAL POLICY AND ADMINISTRATION
}

\section{Edited by Catherine Jones Finer}

\section{Social Policy and}

Administration is an

independent, international source

of information and analysis for

policy-makers, researchers,

fieldworkers, teachers and

students. It covers all aspects of the subject - including issues of employment, social security, health care, housing, education and personal/community social service.
Recent themes (1994):

- "Relatives and absolutes" in social policy papers by Donnison, Gough, Mishra, Weale and Wilding

- Special number on North America

- Strategies and tactics of health service and community care 'reform'

- Special number on Asia Pacific

ORDER FORM

Subscription Rates, Volume 29, 1995 ISSN 0144-5596

Individuals §41.00 UK/Europe, \$79.50 N America*, \&53.00 Rest of World Institutions \$100.00 UK/Europe, \$201.00 N America*, \&129.50 Rest of World

Published quarterly Canadian customers please add 7\% GST

$\square$
$\square$
$\square$

Please enter my subscription/send me a sample copy

I enclose a cheque/money order payable to Basil Blackwell

Please charge my American Express/Diners Club/Mastercard/Nisa account number Expiry Date

Signature Date

Name

Address

Postcode

E-Mail Address: jn/samples@cix.compulink.co.uk (Please include the name of the joumal)

Payment must accompany orders

Please retum this form to: Joumals Marketing, Blackwell Publishers, 108 Cowley Road, Oxford, OX4 1JF, England. Or to: Joumals Marketing, SPOL, Blackwell Publishers, 238 Main Street,

Cambridge, MA 02142, USA

\section{Blackwell Publishers Oxford, UK and Cambridge, USA}



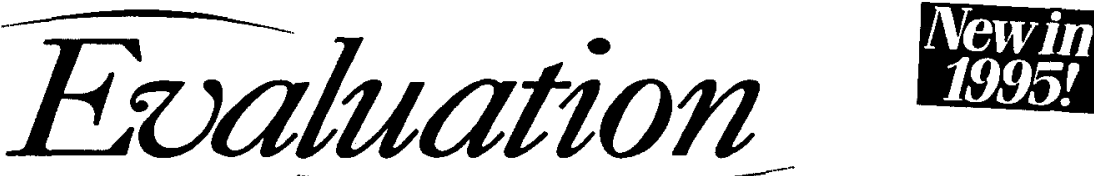

The International Journal of Theory, Research and Practice

Edited by Elliot Stern Tavistock Institute, London

"The creation of a new evaluation journal in Europe is a landmark event. Without doubt, the new journal will be a major force in shaping new ideas and a sense of community in this emerging discipline."

\section{Ernest House}

Over the last two decades there has been a great upsurge in the level of evaluation as an activity and tool of public policy. Evaluation is being launchedto promote dialogue internationally and build bridges within this expanding field.

Evaluation will be interdisciplinary and will welcome contributions from across the social sciences and related disciplines. The journal will encourage dialogue between different evaluation traditions and will also bridge domains where evaluation is currently taking place.

\section{Themes to be covered:}

- influences shaping evaluation practice

- quality assurance in evaluation

- methodological innovations

- cross-cultural and multicultural perspectives

- evaluation and the policy process

- evaluation and theory development

- educating evaluators

\section{Individual Rate \\ Introductory One Year Rate \\ E14 (usual rate $€ 18$ ) $/ \$ 23$ (usual rate \$29) \\ Institutional Rates \\ One Year $\epsilon 60 / \$ 96$ \\ Evaluation will be published in July and October 1995 and will be quarterly from 1996. \\ ISSN: $1356-3890$}

\section{Order Form}

Send this order form to:

SAGE Publications

6 Bonhill Street, London EC2A 4PU, UK Tel: +44 (0)171-374 0645

US Orders to:

SAGE Publications, PO Box 5096, Thousand Oaks, CA 91359, USA

0 Yes! I want to enter my subscription to Evaluation at the introductory rate

0 Individual Rate at $£ 14\left(\$ 18^{*}\right) / \$ 23\left(\$ 29^{*}\right)$ - Usual 1995 rate

Institutional Rate at $£ 60 / \$ 96$

Name

Address

Daytime Tel:

al enclose a cheque (made payable to Sage Publications)

OPlease charge my credit card

$\square$ Mastercard $\square$ Visa $\square$ American Express Diner's Club $\square$ Eurocard

Card Number $\square \square \longrightarrow \square \perp \perp \mid \square \square \square$

Expiry Date / .

Signature

Date 


\section{NOTES TO CONTRIBUTORS}

\section{GUIDELINES}

The distinctive readership of the Journal, cutting across academic disciplines and national boundaries, makes the following points of particular importance to contributors.

"Whatever the specific subject matter, the relevance of conclusions to a broad understanding of policvmaking should be made explicit.

*Whatever the national setting, the extent to which conclusions are generalizable to mans nations should be explicitly discussed.

*Each article should show an awareness of the constraints that public institutions place upon policymaking.

* Jargon should be avoided; technical terms not widely understood should be clearly defined; and the conclusions of statistical analyses should be set out in prose, as well as being supported by quantitative information in tables, footnotes and text as appropriate

\section{PREPARATION OF MANUSERIPT}

The entire manuscript, including footnotes and references, should be typed double-spaced on one side only of $\mathrm{A}_{4}$ size paper, with a left-hand margin of at least $1_{\frac{3}{4}}^{3}$ inches $\left(4^{\frac{1}{2}} \mathrm{~cm}\right)$. Manuscript pages should be numbered consecutively.

The title of the article and the author's name and address should be typed on a separate page at the beginning of the article.

The second page should contain an abstract of not more than 150 words and the title of the article, but not the author's name.

Tables and figures should be numbered consecutively in separate series. Each table or figure should be typed or drawn on a separate sheet. Every table or figure should have a title or caption and at least one reference in the text to indicate its approximate location.

When an article has been accepted for publication, the author is strongly encouraged to send a copy of the final version on computer disk (Apple Macintosh or IBM compatible PC) together with the hard copy typescript, giving details of the wordprocessing software used (Microsoft Word, Word or Word Perfect). However, the publisher reserves the right to typeset material by conventional means if an author's disk proves unsatisfactory.

\section{STYLE}

Spelling, capitalization and punctuation should be consistent within each article. Detailed advice on all matters of style is contained in Judith Butcher's book. Copvediting, Cambridge University Press (1902).

Headings of not more than two grades should be used and they should be typed on separate lines.

Numbered footnotes should be avoided; citation of references in the text is the norm. If there are a few points that require discussion in the article but not in the body of the text, numbered feotnotes mas be used. Thes mas also be useful for technical details, e.g. statistical points that would interrupt the flow of the text. Numbered footnotes should be typed consecutively, doublespaced, at the end of the paper, starting on a new page.

References to publications should be placed in the text. Examples of correct styling for bibliographic citation where the author's name is mentioned in the text are Alford (1975), Biller $(1976,136-7)$, May and Wildavsky (1978), Ostrom, Parks and Whitaker (1978) and subsequently Ostrom et al. (1978).

At the end of the paper, all references should be consolidated in a single alphabetical list starting on a new page. Authors are particularly requested to verify that each text reference appears in the list, and vice versa. In addition to author(s) surname and first name(s) or initial(s), and the title of the book or article, references to books should always include the city of publication and publisher, and for journal articles the volume and part number For example:

Alford, R. (1975) Health Care Politics. Chicago: University of Chicago Press.

Biller, R. (1976) On tolerating policy and organizational termination: some design considerations, Policy Sciences, 7, 2, 133-49.

Campbell, I). (1971) Reforms as experiments. In F. Caro (ed.), Readings in Eivaluation Research. New York: Russell Sage.

May, J. and A. Wildavsky (eds.) (1978) The Policy Cycle, Beverly Hills: Sage.

\section{SUBMISSION}

Please submit the original manuscript plus three copies to: Professor Richard Rose, Journal of Public Policy. Centre for the Study of Public Policy, University of Strathelyde, Livingstone Tower, Glasgow, Gi I XH, Scotland.

\section{COPYEDITING ANI PROOF -}

\section{READING}

The editor and publishers reserve the right to copyedit and proof all items accepted for publication. Authors will review their copvedited manuscripts only if substantial changes have been made. Manuscripts which do not conform to the requirements about style and format may be returned for retyping.

Page proofs of articles will be sent to authors for correction of typographical errors only. Authors must notify the editorial office of any corrections within one week of receipt or approval will be assumed.

Submission of an article or other item implies that it has not been published or accepted for publication elsewhere. Authors are responsible for obtaining written permission to publish material for which they do not own the copyright. Contributors of material accepted for publication will be asked to assign their copyrights to Cambridge University Press.

Fifty offprints will be supplied without charge to the (first) author of each article. Additional copies may be purchased if ordered at proof stage. 


\section{Journal of Public Policy isss $0.4383_{4} \times$}

VOLUME 15 PART i January-April 1995

\section{ARTICLES}

I Oddbjørn Knutsen

The Impact of Old Politics and New Politics Value Orientations on Party Choice-A Comparative Study

65 Gi-Heon Kwon

The Declining Role of Western Powers in International Organizations: Exploring a New Model of U.N. Burden Sharing

89 Claire Wallage and Andri Palyanitsya

East-West Migration and the Czech Republic 